\title{
Agricultural Distortions in Sub-Saharan Africa: Trade and Welfare Indicators, 1961 to 2004
}

\author{
Johanna L. Croser and Kym Anderson
}

\begin{abstract}
For decades, agricultural price and trade policies in Sub-Saharan Africa hampered farmers' contributions to economic growth and poverty reduction. This paper draws on a modification of so-called trade restrictiveness indexes to provide theoretically precise partial-equilibrium indicators of the trade and welfare effects of agricultural policy distortions to producer and consumer prices in 19 African countries since 1961. Annual time series estimates are provided not only by country but also, for the region, by commodity and by policy instrument. The findings reveal the considerable extent of policy reform over the past two decades, especially through reducing export taxation; but they also reveal that national policies continue to reduce trade and economic welfare much more in Sub-Saharan Africa than in Asia or Latin America. JEL classifications: F13, F14, F15, N57, Q17, Q18
\end{abstract}

In the 1960s and 1970s, governments of many Sub-Saharan African countries adopted macroeconomic, sectoral, trade and exchange rate policies that directly or indirectly taxed farm household earnings, particularly from export commodities. These anti-agricultural, anti-trade, welfare-reducing policies, which were also prevalent in numerous other developing country regions up to the early 1980s (Krueger, Schiff and Valdes 1988), have since been subject to major reform. How far has that reform effort gone in altering the trade- and welfare-reducing characteristics of farm and food policies in Sub-Saharan Africa? This matters greatly for economic development and poverty alleviation, because 60 percent of Sub-Saharan Africa's workforce is still employed in agriculture, nearly 40 percent of the population is earning less than $\$ 1 /$ day, and more than 80 percent of the region's poorest households depend directly or indirectly on farming for their livelihoods (World Bank 2007, Chen and

Kym Anderson (corresponding author, kym.anderson@adelaide.edu.au) is George Gollin Professor of Economics at the University of Adelaide in Australia, and former Lead Economist (Trade Policy) in the Development Research Group of the World Bank in Washington DC. Johanna Croser (johlou@ gmail.com) at the time of preparing this paper was a $\mathrm{PhD}$ candidate in the School of Economics at the University of Adelaide, and is currently a commercial lawyer with the law firm Johnson Winter and Slattery in Sydney, Australia.

THE WORLD BANK ECONOMIC REVIEW, VOL. 25, NO. 2, pp. 250-277

doi:10.1093/wber/lhr012

Advance Access Publication May 23, 2011

(C) The Author 2011. Published by Oxford University Press on behalf of the International Bank for Reconstruction and Development / THE WORLD BANK. All rights reserved. For permissions, please e-mail: journals.permissions@oup.com 
Ravallion 2010). Furthermore, because Africa is the focus of several new major agricultural development assistance programs, there is an on-going need to monitor the extent of changes over time in market-distorting policy interventions by national governments.

The present paper serves two purposes. First, it briefly outlines a methodology appropriate for both assessing trends and fluctuations in past policy choices and monitoring annual changes in those policies as soon as data become available each year. And second, it provides estimates for the past halfcentury which indicate the changing extent of government intervention in the region's agricultural markets. Those indicators also reveal the contributions of different countries, commodities and policy instruments to the region's overall reform of agricultural and food policies.

The indicators of price distortions draw on the family of trade restrictiveness indexes, which in turn draw on - but go beyond - the type used by the OECD Secretariat for monitoring agricultural and food policies of high-income countries (producer and consumer support estimates, see OECD 2010). More specifically, they indicate what trade tax, if applied equally to all farm products for a country, would generate the same trade- (or welfare-)reducing outcome as the actual national structure of producer and consumer price distortions in place in any year. In doing so, a methodological advance is made by incorporating nontradable products in our estimates of the indexes, which turns out to be important in the African agricultural policy context.

Economy-wide computable general equilibrium models also are able to provide estimates of the trade and welfare effects of policies for a point in time. However, for lack of econometric estimates such models typically depend on myriad assumptions about parameter values. Furthermore, they apply to just one particular previous year and, being data intensive, tend to be updated infrequently and with a long delay. They are thus unable to provide annual revisions of time series trends and fluctuations on the regular, comparable, and timely basis desired by the policy community.

Data for construction of the indexes reported below come from the World Bank's Distortions to Agricultural Incentives database (Anderson and Valenzuela 2008). The database gives consistent measures of price-distorting policies for 75 countries for the period 1955 to 2007 . The data for the 21 African countries in that database are discussed comprehensively in Anderson and Masters (2009), but that study did not include estimates of the indexes reported below. In this paper we focus on 19 of those African countries, leaving aside Egypt and South Africa because they are large and far more affluent than the rest of the sample. The sub-sample comprises five countries of eastern Africa (Ethiopia, Kenya, Sudan, Tanzania, and Uganda), four in southern Africa (Madagascar, Mozambique, Zambia, and Zimbabwe), five large economies in Africa's western coast (Cameroon, Côte d'Ivoire, Ghana, Nigeria, and Senegal), and five smaller economies of West and Central Africa for which cotton is a crucial export (Benin, Burkina Faso, Chad, Mali, and 
Togo). We concentrate on 1961 to 2004, since those are the years for which the African data are most complete.

The paper is structured as follows: the next section summarizes the methodology to be used. This is followed by a discussion of the data in the World Bank's Agricultural Distortions database. We then report estimates of the series of indexes, before drawing conclusions.

\section{METHODOLOGY}

There is a growing literature that identifies ways to estimate indicators of the trade- and welfare-reducing effects of international trade-related policies as scalar index numbers. This literature serves a key purpose: it overcomes aggregation problems (across different intervention measures and across industries) by using a theoretically sound aggregation procedure to answer precise questions regarding the trade or welfare reductions imposed by each country's trade and trade-related policies.

These measures represent a substantial improvement on commonly used measures. The usual tools for summarizing price-distorting policy trends in a country or region (see, e.g., Anderson and Masters 2009) are measures of the unweighted or weighted mean nominal rate of assistance (NRA) and consumer tax equivalent (CTE), the standard deviation of industry NRAs for the sector, and in a few instances the weighted mean NRA for exportable versus importcompeting covered products. ${ }^{1}$ Authors often need to report more than one measure to gain an appreciation of the nature of the policy regime. For example, indicators of dispersion of NRAs are a reminder that there are additional welfare losses from greater variation of NRAs across industries within the sector (Lloyd 1974). Further, if import-competing and exportable sub-sectors have NRAs of opposite sign, they need to be reported separately because they would offset each other in calculating the aggregate sectoral NRA.

While those various indicators are useful as a set, policy makers would find it more helpful to have a single indicator to capture the overall trade or welfare effect of an individual country's regime of agricultural price distortions in place at any time, and to trace its path over time and make cross-country comparisons. To that end, the scalar index literature has been developed. The pioneering theoretical work is by Anderson and Neary (summarized in their 2005 book), with an important partial equilibrium contribution by Feenstra (1995). The theory defines an ad valorem trade tax rate which, if applied uniformly across all tradable agricultural commodities in a country will generate the same

1. The OECD (2010) measures similar indicators to the NRA and CTE, called producer and consumer support estimates (PSEs and CSEs). The main difference from an African viewpoint, apart from the CSE having the opposite sign to the CTE, is that the NRA and CTE are expressed as a percentage divergence from undistorted (e.g., border) prices whereas the PSEs/CSEs relate to the divergence from actual (distorted) prices. 
reduction in sectoral trade, or in economic welfare, as the actual cross-product structure of distortions. $^{2}$

In recent years, several empirical papers have provided series of estimates of scalar index numbers for individual countries. Irwin (2010) uses detailed import tariff data to calculate the Anderson-Neary Trade Restrictiveness Index for the United States in 1859 and annually from 1867 to 1961; Kee, Nicita and Olarreaga (2009) estimate indexes for 78 developing and developed countries for a single point in time (the mid-2000s); and Lloyd, Croser and Anderson (2010) estimate indexes for 75 developed and developing countries using the World Bank's Distortions to Agricultural Incentives database for the period 1955 to 2007.

In addition to being useful in summarizing the agricultural and food policy regime in an individual country, the Anderson-Neary scalar index measures can be adapted to reveal two other aspects of agricultural policy: the relative contributions of different policy instruments to reductions in trade or welfare (Croser and Anderson 2011), and the trade- and welfare-reducing effects of policy in a single global or regional commodity market (Croser, Lloyd and Anderson 2010). In this paper we utilise the methodology to estimate all three types of indexes. In doing so, we extend the theory and analysis to include nontradables, which have not been addressed in previous studies but which are of practical significance in poorer African countries where nontradables account for a non-trivial share of the gross value of agricultural production.

\section{Country level trade- and welfare-reduction indexes}

To capture distortions imposed by each country's border and domestic policies on its trade volume and economic welfare, we adopt the methodology from Lloyd, Croser and Anderson (2010). Those authors define a Trade Reduction Index (TRI) and a Welfare Reduction Index (WRI) and estimate them by considering separately the distortions to the producer and consumer sides of the agricultural sector (which can differ when there are domestic measures in place in addition to or instead of trade measures). As their names suggest, the two indexes respectively provide a single indicator the (partial equilibrium) of the trade- or welfare-reducing effects of all distortions to consumer and producer prices of farm products from all agricultural and food policy measures in place. The TRI and WRI thus go somewhat closer to what a computable general equilibrium (CGE) can provide in the way of estimates of the trade and welfare (and other) effects of price distortions, while having the advantage of providing an annual time series. Fortuitously, estimates of the actual price distortions are

2. Other indexes define an ad valorem trade tax rate which, if applied uniformly across all tradable products, will generate the same government revenue (Bach and Martin 2001), or the same real national income and general equilibrium structure of the economy (Anderson 2009a), as the actual cross-product structure of distortions. 
available in the NRAs and CTEs of the World Bank's Distortions to Agricultural Incentives database.

The derivation of the two indexes for $n$ import-competing industries leads to the expressions for the TRI and WRI for the import-competing sector of a country shown in Box 1.

Box 1: Expressions for the TRI and WRI

\begin{tabular}{ll}
\hline TRI & WRI \\
\hline$T=\{R a+S b\}$, with & $W=\left\{R^{\prime 2} a+S^{\prime 2} b\right\}^{1 / 2}$, with \\
$R=\left[\sum_{i=1}^{n} r_{i} u_{i}\right]$ and $S=\left[\sum_{i=1}^{n} s_{i} v_{i}\right]$ & $R^{\prime}=\left[\sum_{i=1}^{n} r_{i}^{2} u_{i}\right]^{\frac{1}{2}}$ and $S^{\prime}=\left[\sum_{i=1}^{n} s_{i}^{2} v_{i}\right]^{\frac{1}{2}}$
\end{tabular}

where $u_{i}=p_{i}^{* 2}\left(d x_{i} / d p_{i}^{C}\right) / \sum_{i} p_{i}^{* 2}\left(d x_{i} / d p_{i}^{C}\right)=\rho_{i}\left(p_{i}^{*} x_{i}\right) / \sum_{i} \rho_{i}\left(p_{i}^{*} x_{i}\right)$

$v_{i}=p_{i}^{* 2}\left(d y_{i} / d p_{i}^{P}\right) / \sum_{i} p_{i}^{* 2}\left(d y_{i} / d p_{i}^{P}\right)=\sigma_{i}\left(p_{i}^{*} y_{i}\right) / \sum_{i} \sigma_{i}\left(p_{i}^{*} y_{i}\right)$,

$a=\sum_{i} p_{i}^{* 2} \mathrm{dx}_{i} / \mathrm{d} p_{i}^{C} / \sum_{i} p_{i}^{* 2} \mathrm{~d} m_{i} / \mathrm{d} p_{i}$, and $b=-\sum_{i} p_{i}^{* 2} \mathrm{dy}_{i} / \mathrm{d} p_{i}^{P} / \sum_{i} p_{i}^{* 2} \mathrm{~d} m_{i} / \mathrm{d} p_{i}$

Variable definitions:

$T$ - Trade Reduction Index; W - Welfare Reduction Index; $R$ - index of average consumer price distortions; $S$-index of average producer price distortions; $R^{\prime}$ - Consumer Distortion Index; $S^{\prime}$ - Producer Distortion Index; $s_{i}$ - the rate of distortion of the producer price in proportional terms; $r_{i}$ - rate of distortion of the consumer price in proportional terms; $u_{i}-$ weight for each commodity in $R$ and $R^{\prime}$, which is proportional to the marginal response of domestic consumption to changes in international free-trade prices and can be written as a function of the domestic price elasticity (at the protected trade situation) of demand $\left(\rho_{i}\right) ; v_{i}-$ weight for each commodity in $S$ and $S$, which is proportional to the marginal response of domestic production to changes in international free-trade prices and can be written as a function of the domestic price elasticity (at the protected trade situation) of supply, $\left(\sigma_{i}\right) ; p_{i}^{*}-$ border price; $p_{i}^{P}=p_{i}^{*}\left(1+s_{i}\right)$ - distorted domestic price; $p_{i}^{C}=p_{i}^{*}\left(1+r_{i}\right)$ - distorted domestic consumer price; $x_{i}=x_{i}\left(p_{i}^{C}\right)$ - quantity of good $i$ demanded (as a function of own domestic price); $y_{i}=y_{i}\left(p_{i}^{P}\right)$ - quantity of good $i$ supplied (as a function of own domestic price); a (b) - weight of consumption (production) in the WRI or TRI, which is proportional to the ratio of the marginal response of domestic demand (supply) to a price change relative to the marginal response of imports to a price change.

Source: Synthesized from Lloyd, Croser and Anderson (2010)

Essentially the import-competing TRI and WRI are constructed from appropriately weighted averages of the level of distortions of consumer and producer prices. The TRI is a mean of order one, and the WRI a mean of order two, but they use the same weights. Because the WRI is a mean of order two, it better reflects the welfare cost of agricultural price-distorting policies because it recognizes that the welfare cost of a government-imposed price distortion is related to the square of the price wedge. It thus captures the disproportionately higher welfare costs of peak levels of assistance or taxation, and is positive regardless of whether the government's agricultural policy is favouring or hurting farmers. 
The TRI and WRI can each be extended so as to add the exportable and nontradable sub-sectors of agriculture (see Appendix). Distortions to exportable industries are inputted into the TRI as negative values because a positive (negative) price distortion in an exporting industry has a trade-expanding (reducing) effect, and thus decreases (increases) the TRI. Distortions to nontradable industries are inputted into the TRI as zero values because a domestic price distortion in a nontradable industry by definition has neither a trade-expanding nor trade-reducing effect for that industry because of its assumed prohibitively high trade costs. ${ }^{3}$

The expressions for the TRI and WRI weights above show that estimates of own-price elasticities are required to compute the indexes. In line with Lloyd, Croser and Anderson (2010), and in the absence of reliable elasticity estimates for all countries and periods, we adopt some simplifying assumptions in this paper. We assume that a country's domestic price elasticities of supply are equal across commodities within a sub-sector, and likewise for domestic price elasticities of demand. This powerful simplifying assumption allows us (in the empirical section below) to find appropriately weighted aggregates of distortions on the production and consumption sides of the market simply by aggregating the change in consumer (producer) prices across commodities and using as weights the sectoral share of each commodity's domestic value of consumption (production) at undistorted prices.

We expect these simplifying elasticity assumptions (which still allow for differences across countries and between the demand and supply elasticities of each product within each country) to have only a small impact on the reported indexes. This is because elasticities appear in both the numerator and denominator of the weight expressions, and therefore cancel each other out to a considerable extent. Further, Kee, Nicita and Olarreaga (2008, p. 677) show that the TRI and WRI can be decomposed into three components (namely, the mean and the variance of the distortion rates and the co-variance between the square of the distortion rate and the appropriate price elasticity). Since the elasticity enters into only the third component (see Appendix), and since in practice that component tends to be small relative to the other two components (as noted by Anderson and Neary (2005) and found empirically by Kee, Nicita and Olarreaga (2009) and Irwin (2010)), errors from adopting these simplifying elasticity assumptions are unlikely to be a major problem. These assumptions also make practical sense in the context of computing time series of indexes for Africa, where there is a dearth of reliable and consistent estimates of price elasticities of demand and supply for different time periods over the

3. It is conceivable that a distortion to the price of a nontradable could have an indirect trade consequence because of non-zero cross-price elasticities of demand or supply between tradables and nontradables. However, as with estimates of NRAs and CTEs, our estimates of TRIs and WRIs assume those cross-price elasticities (and also those between tradable products) are zero. We make this assumption not only to simplify greatly the algebra but also because reliable estimates of all the relevant cross elasticities for Africa over the 45-year period under review are unavailable. 
past half-century for each of the covered agricultural products in each of our focus countries. ${ }^{4}$

\section{Policy instrument trade and welfare reduction indexes}

The above country-level TRI and WRI measures are the aggregate of the tradeor welfare-reducing indicators of all the policy measures in place. The variables $s_{i}$ and $r_{i}$, as domestic-to-border price ratios, can theoretically encompass distortions provided by all trade tax/subsidy and non-tariff trade measures, plus domestic price support measures (positive or negative), plus direct interventions affecting farm input prices. Furthermore, where multiple exchange rates operate, the measures can encompass an estimate of the import or export tax equivalent of that distortionary regime too.

Whilst it is desirable to have such an aggregated country level indicator that is so encompassing, agricultural policy analysts are sometimes interested also in indicators of the relative contribution of different policy instruments to reductions in trade or welfare. To provide this insight, it is possible to use the Anderson-Neary framework to construct indexes of policy distortions at the instrument level to facilitate this comparison. ${ }^{5}$

To capture distortions imposed by each African country's different policy instruments on its trade volume and its economic welfare, we adopt the methodology from Croser and Anderson (2011). These authors define an Instrument Trade Reduction Index (ITRI) and an Instrument Welfare Reduction Index (IWRI), which can be estimated by considering the distortion from a single policy instrument to the producer and consumer sides of the market.

The methodology in Croser and Anderson (2011) identifies four types of border distortions (import taxes and subsidies, and export taxes and subsidies), for which individual ITRI and IWRI series can be estimated. In addition to the border measures, the series for domestic distortions in the form of production, consumption and input taxes and subsidies can be estimated. To estimate the trade-reducing effect of an individual instrument, those authors derive expressions for the change in import volume from the individual policy measures, which are used as the basis for deriving ITRIs. To estimate the welfare-reducing effect of individual instruments, those authors make an assumption about the allocation of the total welfare loss from the combination of individual policy instruments. They assume that border measures are applied first, and that this may be supplemented by additional domestic price

4. Sensitivity analysis by Croser, Lloyd and Anderson (2010) shows little difference in the overall TRI and WRI estimates for commodities globally when differentiated elasticity estimates from Tyers and Anderson (1992) were used in place of common ones in each country.

5. Note that most of the series of TRI and WRI indicators in the literature are for single instruments anyway. For example, Irwin (2010) uses only import tariffs, and Kee, Nicita and Olarreaga (2009) report two series of indexes - one based on tariffs only, the other on tariffs plus non-tariff import barriers. 
distortions (which, in practice for Africa, are relatively minor). Thus the domestic distortion's welfare reduction is the residual from subtracting the border measures' effects from the total welfare reduction of all policy measures. This allocation assumption provides a lower-bound on welfare losses from border measures and an upper-bound on welfare losses from domestic measures.

The derivation of the ITRI and IWRI follows essentially the same steps as those for the country-level indexes which encompass all forms of price distortion. The difference in the algebraic methodology is to specify separate indexes for the nine different types of policy instrument (for details see Croser and Anderson 2011). Simplifying assumptions can be made in the absence of reliable price elasticity estimates, and again these assumptions have a minimal effect on the estimates.

\section{Commodity market trade and welfare reduction indexes}

In addition to constructing country-level and instrument-specific indexes, this paper makes use of another methodology within the Anderson-Neary framework to analyse a different aspect of agricultural policy in Sub-Saharan Africa. We construct indexes that show the extent to which African markets for individual farm commodities are distorted relative to others. We employ the methodology in Croser, Lloyd and Anderson (2010) for this purpose. This methodology is novel because whereas all previous work within the trade restrictiveness indexes literature has focused on constructing index numbers of distortions from the perspective of a single country, this methodology instead takes a regional view of individual commodity markets.

The regional commodity TRI (WRI) is equal to the uniform trade tax that has the same effect on regional trade volume (welfare) as the existing set of distortions in the region's national commodity markets. The measures are constructed in the same way as those for individual country indexes, except that instead of summing across distortions in different industries for a single country, the measures are constructed by summing across distortions in different countries for a single commodity. The indexes are computed using data on the domestic production and consumption sides of the region's national commodity markets, and the measures account for all forms of border and domestic price distortions in each country for the commodity market of interest, as well as incorporating import-competing and exportable countries into the measure.

\section{Distortions to Agricultural Incentives database}

This study makes use of the World Bank's Distortions to Agricultural Incentives database (Anderson and Valenzuela 2008). The database is an output from a global research project seeking to improve the understanding of agricultural policy interventions and reforms in Asia, Europe's transition economies, Latin America and the Caribbean as well as Africa. The database 
contains annual estimates of nominal rates of assistance (NRA) (positive or negative) for key farm products in 75 countries that together account for between 90 and 96 percent of the world's population, farmers, agricultural GDP, and total GDP. There are 21 African countries in the database.

We concentrate on the sample of 19 Sub-Saharan African countries listed in the introduction, excluding relatively affluent Egypt and South Africa. For those 19 African focus countries, the database contains around 6000 consistent estimates of annual NRAs to the agricultural sector between 1955 and 2004 or 2005, and the same number of CTEs. Country coverage up to 1960 is much less than from 1961, so the series of estimates presented in this paper begins in that latter year.

The estimates of NRA and CTE in the database are at the commodity level and cover a subset of 41 agricultural products in Africa. These so-called covered products account for around 70 percent of each country's total agricultural production over the period studied. The data identifies each year whether each commodity in each country is considered an importable, exportable or nontradable, a status that may change over time. In the 19 African focus countries, tradable products account for between 40 and 55 percent of the gross value of production of all covered agricultural products (last column of Table 1).

The range of policy measures included in the NRA estimates in the Distortions to Agricultural Incentives database is wide. By calculating domestic-to-border price ratios, the estimates include assistance provided by all tariff and nontariff trade measures, plus any domestic price support measures (positive or negative), plus an adjustment for the output-price equivalent of direct interventions affecting prices of farm inputs. Where multiple exchange rates operate, estimates of the import or export tax equivalents of that distortion are included as well. The range of measures included in the CTE estimates include both domestic consumer taxes and subsidies and trade and exchange rate policies, all of which drive a wedge between the price that consumers pay for each commodity and the international price at the border.

Anderson and Masters (2009) note several patterns that emerge in the distortions to agricultural incentives in the focus countries. In the 1960s and 1970s, many African governments had macroeconomic, sectoral and trade policies that increasingly favored the urban sector at the expense of farm households, and favored production of import-competing farm goods at the expense of exportables. The policy regime was characterized as pro-urban (antiagricultural) and pro-self-sufficiency (anti-agricultural trade). Since the 1980s, Africa has reduced its anti-agricultural and anti-trade biases, but many distortions still remain.

For the countries in this study, Table 1 and Figure 1 illustrate those patterns. The weighted average NRA for the 19 countries is almost always below zero, indicating that agricultural price, trade and exchange rate policies together have reduced the earnings of farmers in these countries. The average rate of 
TABLE 1. Nominal Rates of Assistance for import-competing, exportable and nontradable covered agricultural products, 19 African focus countries, ${ }^{\mathrm{a}} 1961$ to 2004

\begin{tabular}{|c|c|c|c|c|c|c|c|}
\hline & \multicolumn{7}{|c|}{ (percent) } \\
\hline & \multicolumn{5}{|c|}{ NRA, agricultural products ${ }^{\mathrm{a}}$} & \multirow[b]{2}{*}{$\begin{array}{l}\text { Standard } \\
\text { deviation } \\
\text { of NRAs }{ }^{b}\end{array}$} & \multirow{2}{*}{$\begin{array}{c}\text { Tradables } \\
\text { share }(\%) \\
\text { of value of } \\
\text { all covered } \\
\text { agricultura } \\
\text { production }\end{array}$} \\
\hline & $\begin{array}{c}\text { Covered } \\
\text { exportables }\end{array}$ & $\begin{array}{c}\text { Covered } \\
\text { importables }\end{array}$ & $\begin{array}{c}\text { All } \\
\text { covered } \\
\text { tradables }\end{array}$ & $\begin{array}{c}\text { Covered } \\
\text { nontradables }\end{array}$ & $\begin{array}{c}\text { All } \\
\text { covered } \\
\text { products }\end{array}$ & & \\
\hline $1961-64$ & -30 & 123 & 3 & 0 & -1 & 34 & 49 \\
\hline $1965-69$ & -39 & 62 & -15 & 0 & -11 & 33 & 55 \\
\hline $1970-74$ & -47 & 30 & -27 & 0 & -17 & 31 & 55 \\
\hline $1975-79$ & -52 & 22 & -30 & -1 & -23 & 37 & 54 \\
\hline $1980-84$ & -47 & 4 & -28 & -1 & -18 & 35 & 46 \\
\hline $1985-89$ & -50 & 49 & -26 & -2 & -15 & 33 & 46 \\
\hline 1990-94 & -49 & 5 & -27 & -2 & -16 & 31 & 41 \\
\hline $1995-99$ & -32 & 3 & -15 & -3 & -10 & 25 & 39 \\
\hline $2000-04$ & -32 & 7 & -16 & -3 & -10 & 26 & 43 \\
\hline
\end{tabular}

Source: Anderson and Valenzuela (2008)

a. Nominal rates of assistance for the 19 African focus countries are weighted by the gross value of production at undistorted prices for the relevant sub-sector.

b. The simple average of the 19 focus countries' standard deviation of NRA around its weighted mean.

Figure 1. Nominal Rates of Assistance for import-competing, exportable and all covered agricultural products, 19 African countries, 1961 to 2004

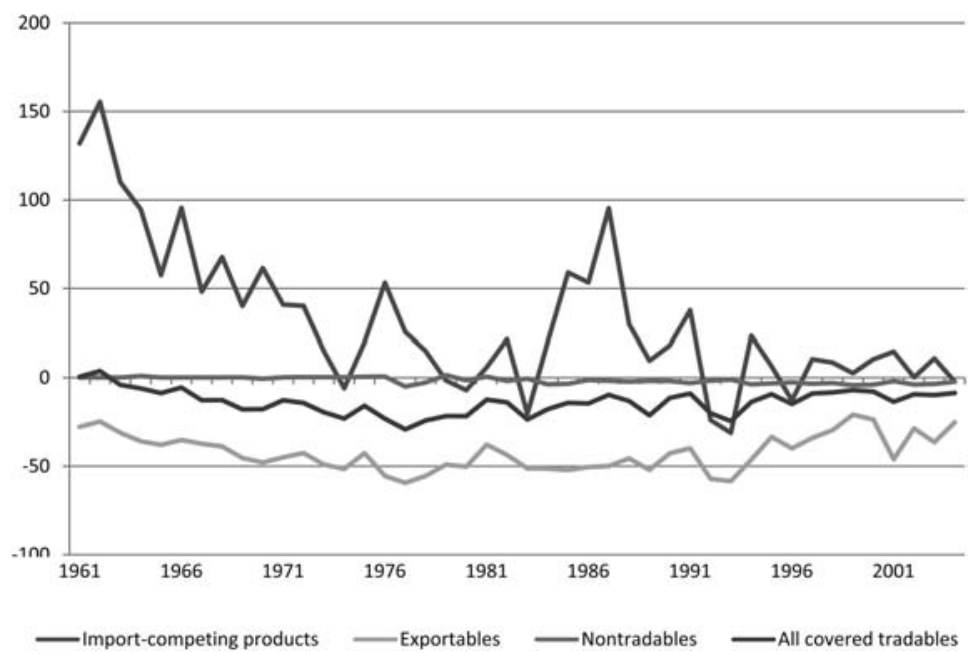

Source: Anderson and Valenzuela (2008). 
TABLE 2. Nominal rates of assistance, all covered agricultural products, 19 African focus countries, 1961 to 2004

\begin{tabular}{|c|c|c|c|c|c|c|c|c|c|}
\hline & \multicolumn{9}{|c|}{ (percent) } \\
\hline & $\begin{array}{c}1961- \\
64\end{array}$ & $\begin{array}{c}1965- \\
69\end{array}$ & $\begin{array}{c}1970- \\
74\end{array}$ & $\begin{array}{c}1975- \\
79\end{array}$ & $\begin{array}{c}1980- \\
84\end{array}$ & $\begin{array}{c}1985- \\
89\end{array}$ & $\begin{array}{c}1990- \\
94\end{array}$ & $\begin{array}{c}1995- \\
99\end{array}$ & $\begin{array}{c}2000- \\
04\end{array}$ \\
\hline Africa & -1 & -11 & -17 & -23 & -18 & -15 & -16 & -10 & -10 \\
\hline Benin & na & na & -3 & -1 & -1 & -1 & -4 & -4 & -1 \\
\hline Burkina Faso & na & na & -2 & -3 & -4 & -1 & -3 & -3 & 0 \\
\hline Cameroon & -4 & -8 & -12 & -25 & -19 & -5 & -4 & -4 & -1 \\
\hline Chad & na & na & -12 & -11 & -8 & -1 & -3 & -3 & -1 \\
\hline Côte d'Ivoire & -29 & -35 & -33 & -40 & -40 & -28 & -22 & -22 & -28 \\
\hline Ethiopia & na & na & na & na & -12 & -15 & -17 & -10 & -7 \\
\hline Ghana & -15 & -28 & -23 & -41 & -32 & -8 & -3 & -5 & -2 \\
\hline Kenya & 13 & -2 & -24 & -15 & -30 & -8 & -30 & -4 & 4 \\
\hline Madagascar & -19 & -23 & -20 & -38 & -51 & -26 & -7 & -4 & 2 \\
\hline Mali & na & na & -6 & -8 & -7 & -3 & -5 & -7 & 0 \\
\hline Mozambique & na & na & na & -56 & -42 & -51 & -4 & 5 & 14 \\
\hline Nigeria & 21 & 12 & 7 & 5 & 8 & 15 & 4 & 0 & -5 \\
\hline Senegal & -15 & -12 & -33 & -34 & -30 & 5 & 7 & -10 & -12 \\
\hline Sudan & -26 & -37 & -48 & -28 & -33 & -39 & -54 & -29 & -15 \\
\hline Tanzania & na & na & na & -50 & -60 & -52 & -30 & -29 & -17 \\
\hline Togo & na & na & -1 & -1 & -2 & -2 & -4 & -3 & -1 \\
\hline Uganda & -3 & -5 & -12 & -24 & -12 & -14 & -1 & 1 & 1 \\
\hline Zambia & -24 & -32 & -42 & -57 & -26 & -68 & -53 & -34 & -36 \\
\hline Zimbabwe & -36 & -36 & -44 & -54 & -47 & -43 & -45 & -38 & -73 \\
\hline
\end{tabular}

Source: Anderson and Valenzuela (2008)

direct taxation (negative NRA) of African farmers rose until the late 1970s before declining by more than half over the next 25 years.

Table 2 reports the country-level NRAs for covered products for each of the 19 countries in this sample. It reveals the considerable diversity within the sample. In some countries - such as Cameroon, Ghana, Senegal, Uganda, Tanzania, and Madagascar - a reduction in the taxing of farmers is evident following the regional peak in 1975-79, while in other countries — such as Cote d'Ivoire, Zambia, and Zimbabwe - high levels of agricultural taxation appear to have persisted.

The country level aggregate measures hide the degree of variation in NRA estimates within countries. Column 6 of Table 1 suggests the standard deviations around the weighted mean NRA for covered products in each country has been high, but has declined somewhat since the mid-1990s. An indication of the extent of variation between groups of products is seen even when comparing the average NRAs for import-competing and exportable product groups (Figure 1). The gap between those two groups' average NRAs has tended to narrow over the period shown, suggesting there has been a decline also in the anti-trade bias in Africa's agricultural policies since the mid-1990s. 
Figure 2. Trade and Welfare Reduction Indexes and Nominal Rate of Assistance for all covered agricultural products, 19 African countries, 1961 to 2004

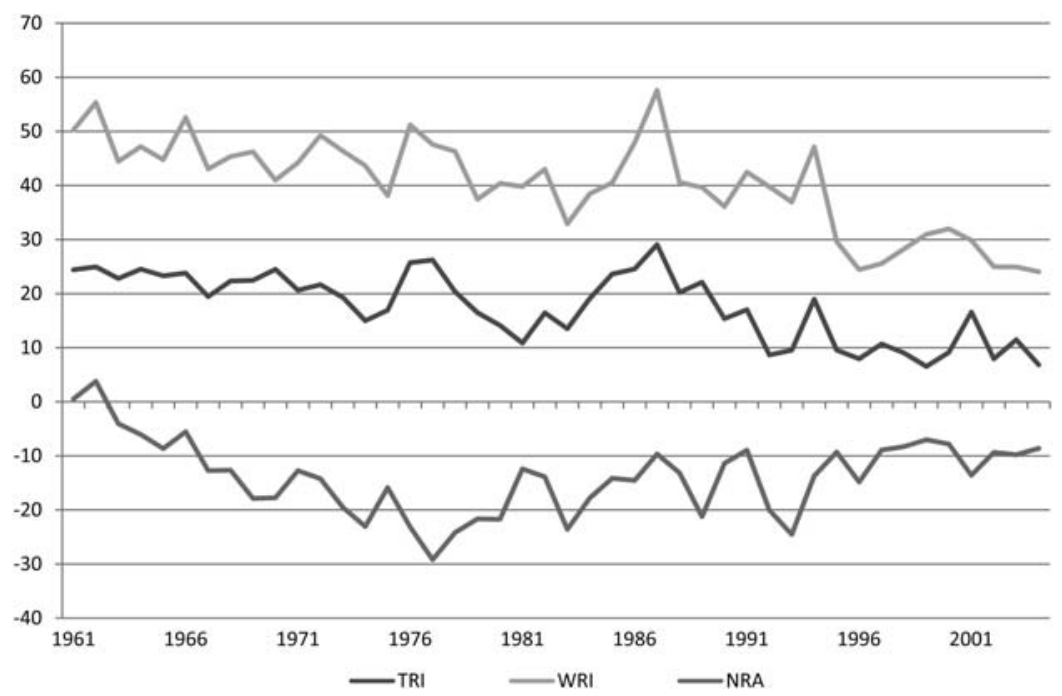

Source: Anderson and Croser (2009).

Notwithstanding their valuable contribution, sectoral averages of NRAs can be misleading as indicators of the aggregate extent of price distortion within the sector. They can also be misleading when compared across countries that have varying degrees of dispersion in their NRAs (and CTEs) for farm products. To see why, we now turn to the TRI and WRI estimates.

\section{TRADE AND WELFARE REDUCTION INDEX ESTIMATES}

The regional aggregate TRI for the 19 African focus countries for all covered products is positive and large over the period under analysis (middle line in Figure 2). The positive TRI indicates that overall agricultural policy in African countries reduced trade. The extent of that has decreased over time, however, with the five-year TRI averages of between 20 and 25 percent in the first two decades of data falling to around 10 percent in the most recent decade. The TRI has the opposite sign to the NRA (see bottom line in Figure 2) because the TRI correctly aggregates the effect of all policies that reduce trade volume, regardless of whether they make a positive or negative contribution to the NRA. The importance of the difference in these aggregations of the trade-reducing effect of policies can be seen in the early 1960s, for example, when the average NRA was around zero but the TRI was quite high (the latter capturing the trade-reducing effect of both import taxes and export taxes, which offset one another in the NRA estimate). Similarly, in the late 1980s the 
NRA changes from around -15 percent to -10 percent at a time when the TRI increases from 20 to 30 percent: the aggregate NRA gives the impression that policies are becoming less distorted in this period but, because the upward trend in the NRA is caused by an increase in import taxes, the TRI correctly reveals that agricultural policies are in fact becoming more trade-restrictive in this time period.

The WRI series for all covered products is necessarily positive and everywhere lies above the TRI series (compare middle and upper lines in Figure 2). The WRI series correctly demonstrates the negative welfare consequences that flow from both negative and positive price distortions. Furthermore, the WRI series provides a better indicator of the welfare cost of distortions than the average level of assistance or taxation, due to the inclusion in the WRI of the 'power of two'. A weighted arithmetic mean does not fully reflect the welfare effects of agricultural distortions because the dispersion of that support or taxation across products has been ignored. By contrast, the WRI captures the higher welfare costs of peak levels of assistance or taxation.

The aggregate African results mask country-level diversity in the TRI and WRI series. Some countries — such as Cote d'Ivoire, Ethiopia, Sudan, Tanzania and Zimbabwe - persistently restricted trade (in aggregate) throughout the period under analysis (Table 3). Other countries - such as Kenya, Mozambique and Zambia — have had periods in which policies in aggregate have expanded agricultural trade slightly (via import subsidies). In terms of the WRI, there is less diversity across countries, since WRI measures are all necessarily positive (Table 4). The extent to which agricultural policy reduced aggregate welfare does differ across countries, however. Some countries have low reductions in welfare, including Uganda and most cotton-exporting countries. Figure 3 provides a snapshot for 2000-04 of the diversity in the WRI and TRI for each of the 19 countries, with the weighted African average in the middle and close to Kenya.

A useful way of understanding the overall welfare reduction for Africa from agricultural policy is to compute the country contributions to the WRI for the 19 African focus countries as a whole. Contributions can be found by computing dollar values of the welfare reduction index for each country (by multiplying the WRI percent by the average of the gross value of production and consumption at undistorted prices). Table 5 shows that Nigeria, Sudan and Ethiopia dominate the region's contributions. The last column of Table 5 reports country contributions to the decline in the regional WRI from its value of 44 percent in $1975-79$ to its value of 27 percent in 2000-04. Nigeria and Sudan dominate that overall reduction, together accounting for around 80 percent of the fall in the WRI. However, Cameroon, Madagascar, Senegal and Uganda have slightly offsetting effects on the regional fall in the WRI over that period.

It is worth noting that the TRI and WRI for all covered products is significantly lower than that for just tradables. This is because nontradables account 
TABLE 3. Trade Reduction Index, all covered agricultural products ${ }^{\mathrm{a}}, 19$ African focus countries, 1961 to 2004

\begin{tabular}{|c|c|c|c|c|c|c|c|c|c|}
\hline & \multicolumn{9}{|c|}{ (percent) } \\
\hline & $\begin{array}{c}1961- \\
64\end{array}$ & $\begin{array}{c}1965- \\
69\end{array}$ & $\begin{array}{c}1970- \\
74\end{array}$ & $\begin{array}{c}1975- \\
79\end{array}$ & $\begin{array}{c}1980- \\
84\end{array}$ & $\begin{array}{c}1985- \\
89\end{array}$ & $\begin{array}{c}1990- \\
94\end{array}$ & $\begin{array}{c}1995- \\
99\end{array}$ & $\begin{array}{c}2000- \\
04\end{array}$ \\
\hline Africa & 24 & 22 & 20 & 21 & 15 & 24 & 14 & 9 & 10 \\
\hline Benin & na & na & 2 & 1 & 1 & 0 & 2 & 3 & 1 \\
\hline Burkina Faso & na & na & 2 & 3 & 4 & 1 & 3 & 3 & 0 \\
\hline Cameroon & 2 & 5 & 6 & 14 & 12 & 3 & 2 & 2 & 1 \\
\hline Chad & na & na & 12 & 11 & 8 & 1 & 3 & 3 & 1 \\
\hline Côte d'Ivoire & 13 & 13 & 24 & 27 & 19 & 17 & 12 & 15 & 22 \\
\hline Ethiopia & na & na & na & na & 14 & 16 & 19 & 11 & 9 \\
\hline Ghana & 6 & 11 & 10 & 22 & 20 & 15 & 7 & 3 & 7 \\
\hline Kenya & -16 & -19 & -4 & 12 & 21 & 19 & -7 & 9 & 11 \\
\hline Madagascar & 20 & 15 & -13 & 6 & -1 & 17 & 3 & 3 & 8 \\
\hline Mali & na & na & 4 & 7 & 6 & 3 & 5 & 7 & 0 \\
\hline Mozambique & na & na & na & 27 & -6 & -14 & 1 & 6 & 24 \\
\hline Nigeria & 39 & 38 & 31 & 18 & 11 & 19 & 7 & 8 & 1 \\
\hline Senegal & 14 & 10 & 30 & 36 & 28 & 25 & 26 & 7 & 12 \\
\hline Sudan & 29 & 28 & 29 & 29 & 22 & 56 & 40 & 17 & 31 \\
\hline Tanzania & na & na & na & 16 & 18 & 34 & 30 & 16 & 17 \\
\hline Togo & na & na & 0 & 1 & 2 & 1 & 4 & 3 & 1 \\
\hline Uganda & 2 & 4 & 8 & 14 & 9 & 10 & 2 & 2 & 1 \\
\hline Zambia & 21 & 1 & 1 & 36 & -11 & -45 & -27 & -7 & 29 \\
\hline Zimbabwe & 33 & 38 & 43 & 51 & 29 & 37 & 19 & 10 & 12 \\
\hline
\end{tabular}

Source: Anderson and Croser (2009) based on NRA and CTE data in Anderson and Valenzuela (2008).

a. Includes all import-competing, exportable and nontradable products, with nontradable sectors assumed to have a zero level of distortion on the volume of trade.

for a large share of the gross value of production and consumption (see final column of Table 1). The TRI estimates for all covered products are roughly half, and WRI estimates are roughly two-thirds, what there are with nontradables excluded.

It is useful to compare the TRI and WRI results for the African focus countries with those for other developing country regions, which are reported in Lloyd, Croser and Anderson (2010). The African focus countries' policies have been, and remain, the most trade- and welfare-reducing. However, all three regions have shown a trend towards less damaging agricultural policies in recent years (Figure 4).

\section{Policy instrument results}

We now turn to the national decompositions of the TRI and WRI to the policy instrument level. Figure 5 provides a summary of the estimates of the contribution to the weighted average WRI series for the 19 African focus countries of four different border measures: taxes and subsidies on both imports and 
TABLe 4. Welfare Reduction Index, all covered agricultural products, 19 African focus countries, 1961 to 2004

\begin{tabular}{|c|c|c|c|c|c|c|c|c|c|}
\hline & \multicolumn{9}{|c|}{ (percent) } \\
\hline & $\begin{array}{c}1961- \\
64\end{array}$ & $\begin{array}{c}1965- \\
69\end{array}$ & $\begin{array}{c}1970- \\
74\end{array}$ & $\begin{array}{c}1975- \\
79\end{array}$ & $\begin{array}{c}1980- \\
84\end{array}$ & $\begin{array}{c}1985- \\
89\end{array}$ & $\begin{array}{c}1990- \\
94\end{array}$ & $\begin{array}{c}1995- \\
99\end{array}$ & $\begin{array}{c}2000- \\
04\end{array}$ \\
\hline Africa & 49 & 46 & 45 & 44 & 39 & 45 & 40 & 28 & 27 \\
\hline Benin & na & na & 9 & 6 & 7 & 4 & 8 & 7 & 4 \\
\hline Burkina Faso & na & na & 9 & 13 & 14 & 5 & 9 & 9 & 9 \\
\hline Cameroon & 9 & 14 & 17 & 29 & 22 & 12 & 11 & 10 & 4 \\
\hline Chad & na & na & 24 & 23 & 20 & 5 & 9 & 8 & 6 \\
\hline Côte d'Ivoire & 28 & 36 & 36 & 40 & 38 & 30 & 25 & 25 & 31 \\
\hline Ethiopia & na & na & na & na & 22 & 24 & 27 & 20 & 16 \\
\hline Ghana & 17 & 30 & 28 & 44 & 49 & 36 & 17 & 11 & 15 \\
\hline Kenya & 35 & 39 & 29 & 34 & 38 & 28 & 35 & 26 & 29 \\
\hline Madagascar & 23 & 27 & 26 & 43 & 55 & 37 & 21 & 11 & 13 \\
\hline Mali & na & na & 16 & 20 & 18 & 8 & 13 & 14 & 9 \\
\hline Mozambique & na & na & na & 63 & 52 & 63 & 18 & 18 & 41 \\
\hline Nigeria & 87 & 78 & 68 & 54 & 45 & 63 & 48 & 36 & 31 \\
\hline Senegal & 17 & 15 & 38 & 41 & 36 & 50 & 55 & 11 & 16 \\
\hline Sudan & 36 & 40 & 51 & 40 & 40 & 65 & 79 & 42 & 44 \\
\hline Tanzania & na & na & na & 58 & 65 & 62 & 53 & 46 & 38 \\
\hline Togo & na & na & 4 & 5 & 9 & 5 & 10 & 8 & 5 \\
\hline Uganda & 6 & 9 & 20 & 35 & 24 & 24 & 4 & 4 & 4 \\
\hline Zambia & 26 & 41 & 47 & 57 & 31 & 69 & 58 & 39 & 42 \\
\hline Zimbabwe & 39 & 45 & 50 & 56 & 46 & 42 & 46 & 40 & 72 \\
\hline
\end{tabular}

Source: Anderson and Croser (2009) based on NRA and CTE data in Anderson and Valenzuela (2008).

exports. The figure demonstrates the very substantial role that export taxes have played in the reduction of welfare in the region. On average, more than half the welfare reductions has come from anti-agricultural export taxing policies over the period studied, but the decline in them has contributed most to reform in recent decades: the gross contribution of export taxes to the reduction in the WRI over the period $1985-89$ to $2000-04$ is 93 percent. The remaining 7 percent is made up of a 34 percent gross contribution from import tax cuts offset by a -28 percent contribution from export subsidies $(-13$ percent) and import subsidies ( -15 percent).

The contributions to TRI and WRI estimates for African countries from domestic distortions are small, never accounting for more than 5 percent of the overall regional TRI or WRI. This can be seen in Table 6. That table also reveals the far greater dominance of export taxation in Africa as compared with developing Asia and Latin America, particularly in the 2000-04 period.

\section{Commodity TRI and WRI results}

The TRI and WRI estimates for individual regional commodity markets provide a different perspective on the level of distortion in the focus countries 
Figure 3. Trade and Welfare Reduction Indexes, all covered agricultural products, 19 African countries and regional average ${ }^{\mathrm{a}}, 2000-04$

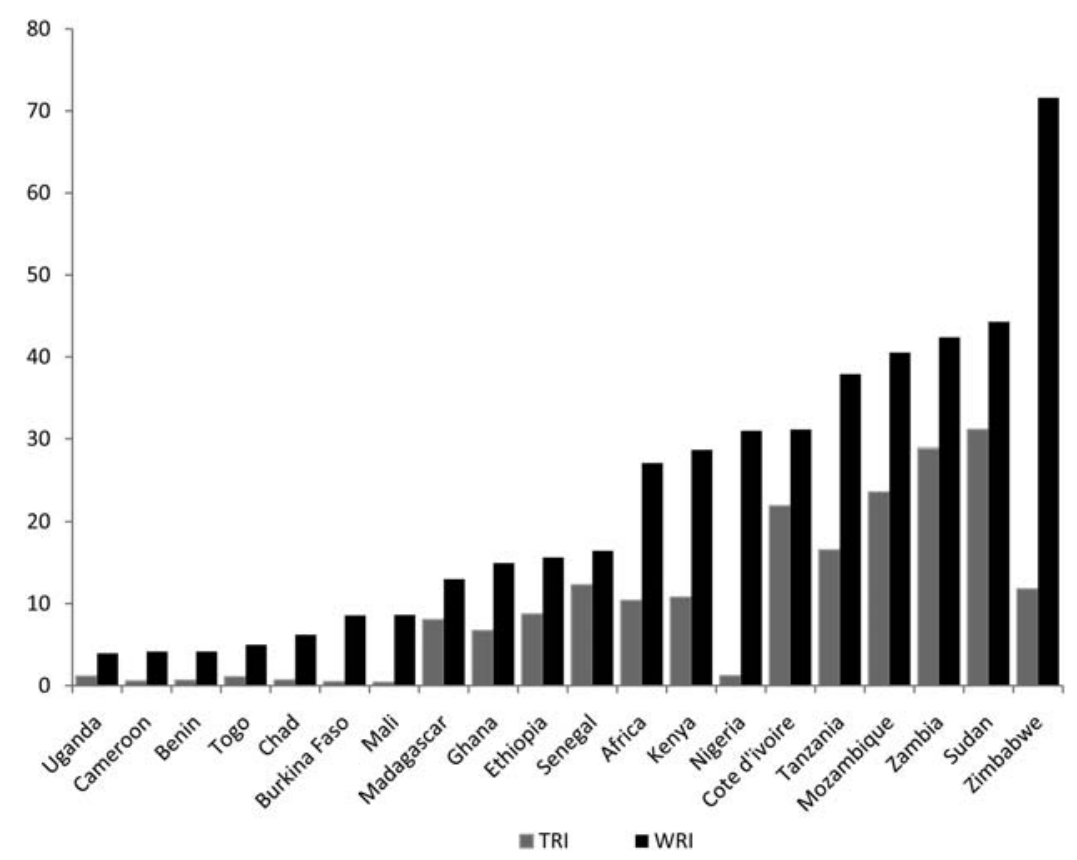

Source: Anderson and Croser (2009)

a. To get the African regional average, the national indexes are weighted by the average of the gross value of production and consumption at undistorted prices.

over the period under analysis. Table 7 reveals considerable diversity in the distortions in different commodity markets in Africa. Fruit and vegetable commodity markets, which tend to have a high share of nontradable production, have low WRI estimates on average, whereas traded commodities such as tropical crops, oilseeds and livestock tend to have more welfare-reducing policies in place. Grains, which comprise a mixture of tradable and nontradable products, had highly-distortionary policies in the 1960s on average, but these have been reduced over time. As of 2000-04, the indexes suggest sugar and cotton markets continue to have highly distorted policies in terms of both the trade and welfare effects of their policies.

\section{CONCLUSIONS}

Reform of agricultural policy in Africa is topical at present. Recently announced international aid and investment programs, domestic policy reforms, and the negotiation of international and regional trade agreements are on the agenda, not to mention climate change. Measurement of intervention levels is required to assess policy initiatives in each of these areas. Certainly 
TABLE 5. Country contributions ${ }^{\mathrm{a}}$ to the regional Welfare Reduction Index for African focus countries, ${ }^{b}$ all covered agricultural products, 1961 to 2004, and to its fall from $1975-79$ to $2000-04$

\begin{tabular}{|c|c|c|c|c|c|c|}
\hline \multirow[b]{2}{*}{ Africa WRI } & \multicolumn{6}{|c|}{ (percent) } \\
\hline & $\begin{array}{c}1961-64 \\
49\end{array}$ & $\begin{array}{c}1970-74 \\
45\end{array}$ & $\begin{array}{c}1980-84 \\
39\end{array}$ & $\begin{array}{c}1990-94 \\
40\end{array}$ & $\begin{array}{c}2000-04 \\
27\end{array}$ & $\begin{array}{l}\text { Contribution } \\
\text { to fall in } \\
\text { WRI between } \\
1975-79 \text { and } \\
2000-04\end{array}$ \\
\hline Cameroon & 2 & 3 & 2 & 1 & 0 & -4 \\
\hline Cote d'Ivoire & 3 & 5 & 6 & 4 & 5 & 1 \\
\hline Ethiopia & - & - & 10 & 10 & 9 & na \\
\hline Ghana & 2 & 3 & 4 & 2 & 3 & 1 \\
\hline Kenya & 2 & 2 & 3 & 3 & 2 & 1 \\
\hline Madagascar & 1 & 3 & 4 & 1 & 1 & -2 \\
\hline Mozambique & - & - & 2 & 1 & 2 & 2 \\
\hline Nigeria & 74 & 51 & 37 & 38 & 35 & 34 \\
\hline Senegal & 1 & 2 & 2 & 2 & 1 & -3 \\
\hline Sudan & 10 & 21 & 18 & 30 & 27 & 44 \\
\hline Tanzania & - & - & 7 & 3 & 6 & 1 \\
\hline Uganda & 1 & 4 & 4 & 0 & 1 & -8 \\
\hline Zambia & 1 & 2 & 1 & 1 & 2 & 1 \\
\hline Zimbabwe & 3 & 4 & 3 & 3 & 5 & 7 \\
\hline Africa & 100 & 100 & 103 & 100 & 100 & 100 \\
\hline
\end{tabular}

Source: Authors' calculations from data in Anderson and Croser (2009).

a. Country contributions are computed by converting national percentage WRIs to dollar values by multiplying by the average of the gross value of production and consumption at undistorted prices.

b. Benin, Burkina Faso, Chad, Mali, and Togo are not shown as each of their contributions was less than 0.5 percent.

economy-wide models can measure the welfare and trade (and other) effects of policy in a particular country or market, and do it better than can partial equilibrium analysis where there are potentially offsetting policies such as import taxes and import subsidies. Such models require, however, reliable data on the structure of the economy and sound econometric estimates of myriad parameters, neither of which are easily found for the poorer countries of Africa. Even where economy-wide models are available, they are calibrated to a particular year (typically $5+$ years ago) and are incapable of providing easily updatable time series indicators of the national and regional effects of distortional policies.

Scalar index measures, by contrast, can provide meaningful partial equilibrium indicators of the welfare and trade effects of policy interventions in agriculture in poorer countries. As demonstrated above, these indexes can be 
Figure 4. Trade- and Welfare-Reduction Indexes, Sub-Saharan Africa, Asia and Latin America, all covered tradable agricultural products, $1960^{\mathrm{a}}$ to 2004
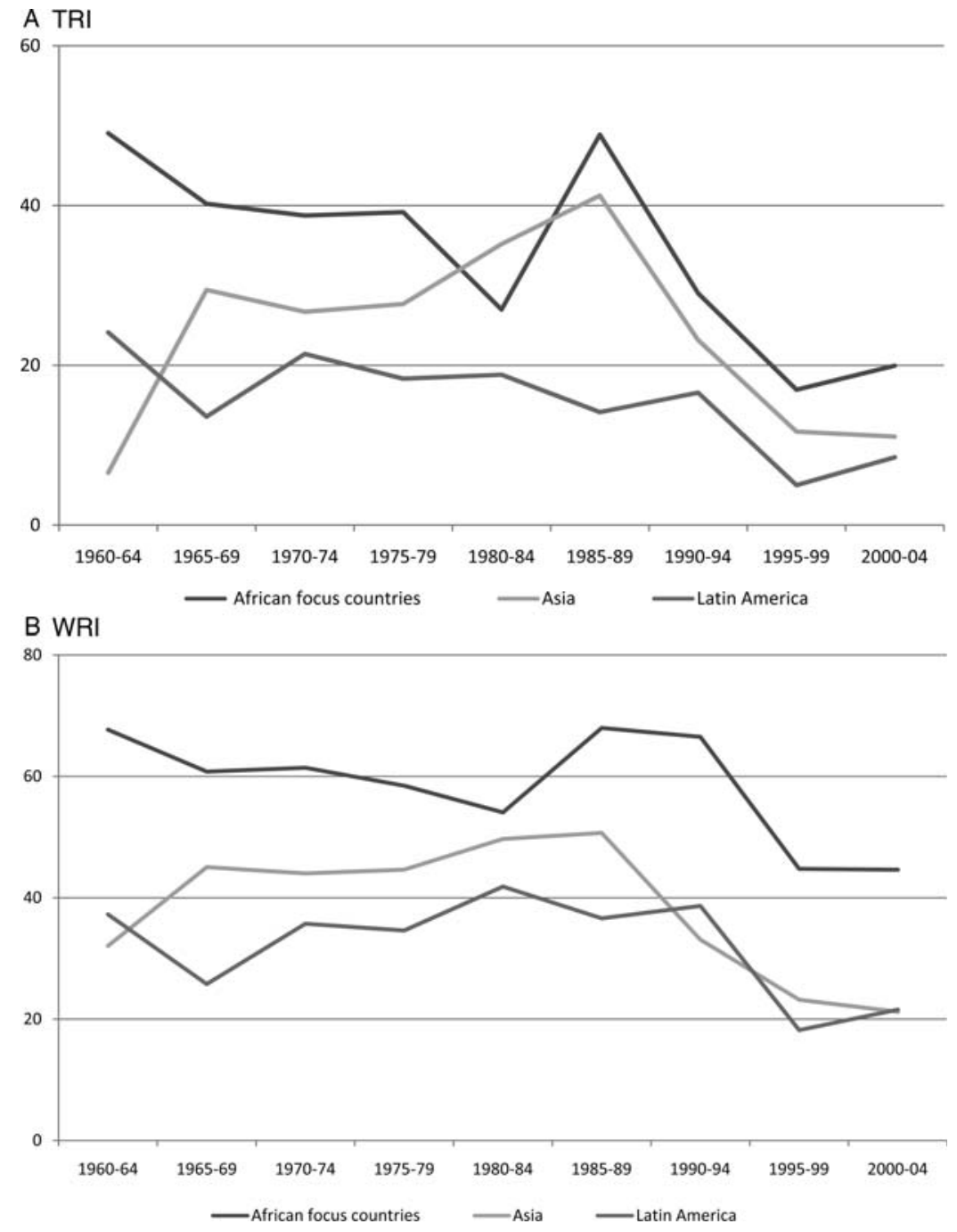

Source: Generated from estimates in Anderson and Croser (2009)

a. The first period is 1961-64 for African countries.

estimated using no more than already available price and quantity data used to generate NRAs and CTEs (or PSEs and CSEs), and so are relatively inexpensive to generate and update annually for timely policy monitoring. ${ }^{6}$

6. This is indeed what is being planned in a new FAO/OECD project called Monitoring African Food and Agricultural Policies, funded by the Bill and Melinda Gates Foundation (see www.fao.org/ mafap). These indexes are also being considered by USAID for inclusion among the policy indicators to be estimated to monitor future policy developments as they affect global hunger and food security (see www.state.gov/s/globalfoodsecurity). 
Figure 5. Decomposition of the Welfare Reduction Index due to border measures, by policy instrument, 19 focus African countries, 1961 to 2004

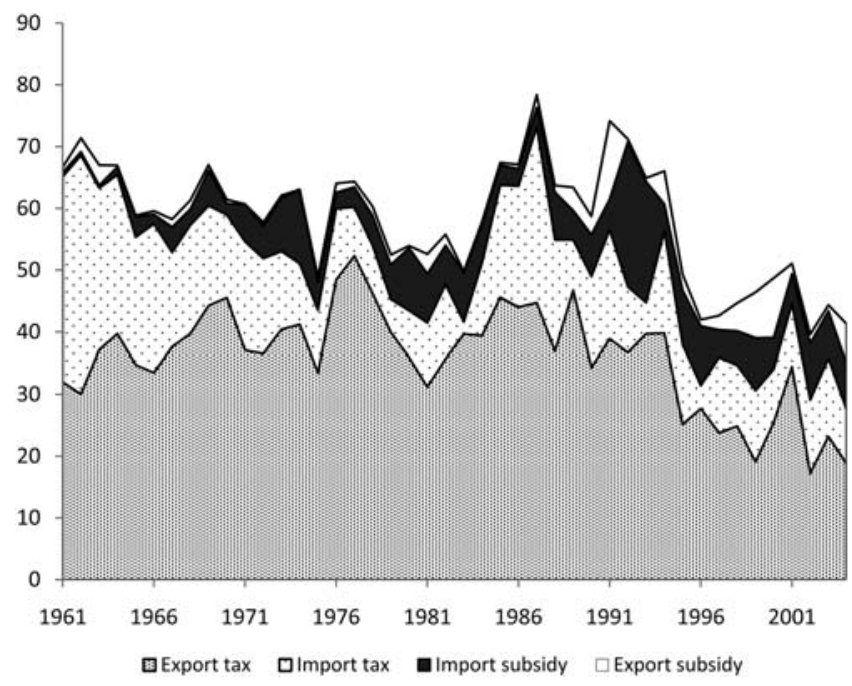

Source: Croser and Anderson (2011).

The scalar index numbers reported in this paper are thus a major supplement to the widely-used price distortion measures such as NRAs or PSEs, because they correctly aggregate offsetting policies and because the WRI properly captures the much higher welfare costs associated with the largest price distortions. True, the indexes measured in this study (like NRAs or PSEs) do not make use of price elasticity estimates, but if and when reliable estimates become available for the many agricultural products of the region, they can be incorporated to revise our estimates. Meanwhile, both theory and other recent empirical studies (see, e.g, Croser, Lloyd and Anderson 2010) provide comfort in suggesting the use of differentiated elasticity estimates across commodities would not make much difference to the results.

The methodology in the paper adopts the standard partial equilibrium approach still presented in most textbooks on trade policy or welfare economics. In particular, it is based on the benchmark of competitive markets. The methodology ignores the existence of divergences such as externalities and governance problems, including administrative costs. The trade and welfare reduction indexes reported above may be over- or under-stated to the extent that such problems exist. For example, in some cases where there is market failure, we know from second-best theory that policies that increase assistance to a lightly protected sector may increase rather than decrease national economic welfare. Even so, the series reported in this paper almost certainly give a better indication of trade and welfare effects of policies than the NRA/CTE measures from which they are built. 
TABLE 6. Contributions from different policy instruments on the production side to the TRI and WRI for covered products by different policy instruments, ${ }^{\text {a }}$ by developing country region, ${ }^{\mathrm{b}} 1980-84$ and 2000-04

\begin{tabular}{|c|c|c|c|c|c|c|}
\hline & \multicolumn{6}{|c|}{ (percent) } \\
\hline & \multicolumn{6}{|c|}{ (a) TRI } \\
\hline & \multicolumn{3}{|c|}{$1980-84$} & \multicolumn{3}{|c|}{$2000-04$} \\
\hline & Africa & Asia & Latin Amer. & Africa & Asia & Latin Amer. \\
\hline All measures & 24 & 37 & 21 & 16 & 10 & 7 \\
\hline Border measures & 22 & 33 & 20 & 13 & 9 & 7 \\
\hline Export tax & 24 & 27 & 21 & 15 & 2 & 6 \\
\hline Export subsidy & -4 & -1 & -1 & -3 & -1 & -3 \\
\hline Import tax & 10 & 9 & 6 & 7 & 10 & 5 \\
\hline Import subsidy & -8 & -2 & -5 & -6 & -1 & -2 \\
\hline Domestic taxes \& subsidies & 2 & 4 & 1 & 3 & 1 & 0 \\
\hline Production tax & 2 & 3 & 0 & 3 & 1 & 0 \\
\hline \multirow[t]{4}{*}{ Production subsidy } & 0 & 0 & 1 & 0 & 0 & 0 \\
\hline & \multicolumn{6}{|c|}{ (b)WRI } \\
\hline & \multicolumn{3}{|c|}{$1980-84$} & \multicolumn{3}{|c|}{$2000-04$} \\
\hline & Africa & Asia & Latin Amer. & Africa & Asia & Latin Amer. \\
\hline All measures & 54 & 61 & 46 & 38 & 20 & 25 \\
\hline Border measures & 48 & 44 & 38 & 33 & 17 & 18 \\
\hline Export tax & 25 & 29 & 23 & 16 & 2 & 7 \\
\hline Export subsidy & 4 & 1 & 1 & 3 & 3 & 3 \\
\hline Import tax & 11 & 12 & 7 & 8 & 12 & 7 \\
\hline Import subsidy & 8 & 2 & 6 & 6 & 1 & 2 \\
\hline Domestic taxes \& subsidies & 6 & 17 & 8 & 5 & 3 & 7 \\
\hline Production tax & 5 & 15 & 1 & 4 & 1 & 2 \\
\hline Production subsidy & 1 & 1 & 8 & 0 & 2 & 5 \\
\hline
\end{tabular}

Source: Croser and Anderson (2011).

a. Each instrument share is computed in the following two steps: (1) indices are converted to constant 2000 \$US by multiplying the index by the average value of production or consumption for that instrument group at the country level; (2) each instrument dollar amount index is divided by the country average value of production or consumption. The measures in the table - which are like a weighted average of an overall regional index - therefore reflect both the absolute size of the index for each policy instrument and the relative importance of that policy instrument in the region.

b. Africa includes Egypt and South Africa (unlike in previous tables); Asia excludes Japan; Latin America includes the Caribbean.

Notwithstanding those caveats, two clear conclusions can be drawn from the empirical estimates presented in this paper. One is that they confirm that there has been very substantial policy reform in African agriculture over recent decades, especially in phasing out export taxation. The other is that they reveal there is still a long way to go before that reform process is complete, since the trade- and 
Table 7. Commodity Welfare Reduction Index, African regional market of 19 focus countries, 31 covered agricultural products, 1961-64 to 2000-04

\begin{tabular}{|c|c|c|c|c|c|c|c|c|c|}
\hline & \multicolumn{9}{|c|}{ (percent) } \\
\hline & $1961-64$ & $1965-69$ & $1970-74$ & $1975-79$ & $1980-84$ & 1985-89 & 1990-94 & 1995-99 & 2000-04 \\
\hline Grains & 59 & 50 & 44 & 34 & 28 & 33 & 26 & 20 & 18 \\
\hline Cassava & 0 & 0 & 1 & 1 & 3 & 1 & 1 & 4 & 3 \\
\hline Maize & 114 & 73 & 63 & 71 & 54 & 67 & 40 & 38 & 35 \\
\hline Millet & 18 & 18 & 11 & 5 & 10 & 13 & 16 & 18 & 8 \\
\hline Rice & 31 & 30 & 40 & 36 & 48 & 60 & 38 & 16 & 18 \\
\hline Sorghum & 153 & 144 & 118 & 95 & 83 & 95 & 80 & 52 & 49 \\
\hline Wheat & 17 & 37 & 40 & 30 & 14 & 16 & 35 & 16 & 16 \\
\hline Oilseeds & 28 & 42 & 54 & 49 & 47 & 40 & 72 & 43 & 36 \\
\hline Cashew & na & na & na & 80 & 80 & 85 & 61 & 13 & 11 \\
\hline Groundnut & 27 & 43 & 54 & 51 & 50 & 35 & 60 & 41 & 47 \\
\hline Oilseed & na & na & na & na & 47 & 52 & 61 & 56 & 42 \\
\hline Palmoil & 25 & 31 & 45 & 26 & 28 & 44 & 132 & 50 & 13 \\
\hline Sesame & 50 & 60 & 62 & 65 & 56 & 44 & 47 & 45 & 38 \\
\hline Soybean & na & 14 & 34 & 44 & 45 & 44 & 56 & 52 & 64 \\
\hline Sunflower & 0 & 0 & 0 & 0 & 0 & 0 & 0 & 0 & 0 \\
\hline $\begin{array}{l}\text { Tropical } \\
\text { crops }\end{array}$ & 36 & 41 & 45 & 61 & 54 & 49 & 53 & 44 & 51 \\
\hline Cocoa & 31 & 51 & 46 & 62 & 54 & 41 & 37 & 37 & 38 \\
\hline Coffee & 39 & 41 & 46 & 64 & 56 & 48 & 47 & 35 & 21 \\
\hline Cotton & 42 & 35 & 44 & 57 & 59 & 59 & 71 & 59 & 64 \\
\hline Sugar & 22 & 35 & 47 & 49 & 43 & 38 & 45 & 45 & 87 \\
\hline Tea & 12 & 8 & 24 & 56 & 52 & 47 & 51 & 50 & 49 \\
\hline Tobacco & 39 & 38 & 48 & 56 & 50 & 50 & 40 & 39 & 58 \\
\hline $\begin{array}{l}\text { Fruit } \& \\
\text { vegetables }\end{array}$ & 0 & 0 & 0 & 4 & 5 & 5 & 2 & 5 & 5 \\
\hline Banana & 2 & 4 & 0 & 2 & 2 & 1 & 5 & 5 & 2 \\
\hline Bean & 7 & 10 & 3 & 48 & 62 & 73 & 35 & 42 & 40 \\
\hline $\begin{array}{c}\text { Roots \& } \\
\text { tubers }\end{array}$ & 0 & 0 & 0 & 0 & 0 & 0 & 0 & 0 & 0 \\
\hline Pepper & na & 42 & 9 & 39 & 47 & 80 & 30 & 62 & 27 \\
\hline Plantain & 0 & 0 & 0 & 0 & 0 & 0 & 0 & 0 & 0 \\
\hline Potato & na & na & na & 0 & 0 & 0 & 0 & 0 & 0 \\
\hline $\begin{array}{l}\text { Sweet } \\
\text { potato }\end{array}$ & 0 & 0 & 0 & 0 & 0 & 0 & 0 & 0 & 0 \\
\hline Yam & 0 & 0 & 0 & 1 & 2 & 1 & 1 & 4 & 4 \\
\hline Livestock & 30 & 36 & 52 & 35 & 33 & 68 & 66 & 40 & 38 \\
\hline Beef & 34 & 42 & 58 & 29 & 29 & 60 & 73 & 43 & 42 \\
\hline Camel & 38 & 60 & 34 & 38 & 34 & 68 & 84 & 49 & 99 \\
\hline Milk & 19 & 16 & 41 & 36 & 29 & 79 & 40 & 30 & 29 \\
\hline Sheepmeat & 42 & 48 & 61 & 46 & 38 & 59 & 70 & 54 & 33 \\
\hline
\end{tabular}

Source: Authors' calculations. 
welfare-reduction indexes associated with the present decade's policies are still substantial and reveal large differences across countries and commodities.

\section{FUNDING}

This work is a product of a World Bank research project on Distortions to Agricultural Incentives (Project P093895, see www.worldbank.org/ agdistortions) which was financially supported by the governments of the Netherlands (BNPP), the United Kingdom (DfID) and Ireland; and by the Australian Research Council (DP0880565).

\section{ACKNOWLEDGEMENTS}

The authors are grateful for helpful referee comments and for the distortion estimates provided by the authors of the various African country case studies, reported in Anderson, K. and W. Masters (eds.), Distortions to Agricultural Incentives in Africa, Washington DC: World Bank, 2009. The views expressed are the authors' alone and not necessarily those of the World Bank and its Executive Directors, nor the countries they represent, nor of the institutions providing the project research funds.

\section{Appendix: Derivation of Trade-And Welfare-Reduction INDEXES}

Lloyd, Croser and Anderson (2010) outline a methodology for computing indexes which accurately capture the state of trade policy regime in an individual country in a theoretically meaningful way. Their methodology, which draws heavily on the Anderson and Neary (2005) methodology, defines partial equilibrium indexes which aggregate the production and consumption sides of the economy separately (instead of trade data as is more commonly done with trade restrictiveness indexes). This form of index is well-suited to agricultural distortions research, where data are available for production and consumption of individual farm commodities. This Appendix briefly outlines that theory for the import-competing sector of a small open economy (with further details and extensions available in Lloyd, Croser and Anderson 2010 and Croser, Lloyd and Anderson 2010).

Consider an individual country and assume it has a small, open economy in which all markets are competitive. The market for an import good may be distorted by a tariff and other nontariff border measures or by behind-the-border measures such as domestic subsidies and price controls. The effect of a country's distortions on its import volume is captured by the Trade Reduction Index (TRI), defined as the uniform tariff rate which, if applied to all goods in the place of all actual border and behind-the-border price distortions, would result in the same reduction in the volume of imports (summed across products by valuing them at the undistorted border price) as the actual distortions. 
Suppose the market for one good, good $i$, is distorted by a combination of measures that distort its consumer and producer prices. For the producers of the good, the distorted domestic producer price, $p_{i}^{P}$, is related to the border price, $p_{i}^{*}$, by the relation, $p_{i}^{P}=p_{i}^{*}\left(1+s_{i}\right)$ where $s_{i}$ is the rate of distortion of the producer price in proportional terms. For the consumers of the good, the distorted domestic consumer price, $p_{i}^{C}$, is related to the border price by the relation, $p_{i}^{C}=p_{i}^{*}\left(1+r_{i}\right)$ where $r_{i}$ is the rate of distortion of the consumer price in proportional terms. In general, $r_{i} \neq s_{i}$. Using these relations, the change in the value of imports in the market for good $i$ is given by:

$$
\begin{aligned}
\Delta M_{i} & =p_{i}^{*} \Delta x_{i}-p_{i}^{*} \Delta y_{i} \\
& =p_{i}^{* 2} d x_{i} / d p_{i}^{C} r_{i}-p_{i}^{* 2} d y_{i} / d p_{i}^{P} s_{i}
\end{aligned}
$$

where the quantities of good $i$ demanded and supplied, $x_{i}$ and $y_{i}$, are functions just of their own domestic price: $x_{i}=x_{i}\left(p_{i}^{C}\right)$ and $y_{i}=y_{i}\left(p_{i}^{P}\right)$.

Strictly speaking, this result holds only for small distortions. In reality rates of distortion may not be small. If, however, the demand and supply functions are linear over the relevant price range, the effect on imports is given by equation (1) with constant slopes of the demand and supply curves $\left(d x_{i} / d p_{i}^{C}\right.$ and $d y_{i} / d p_{i}^{P}$, respectively). If the functions are not linear, this expression provides an approximation to the loss.

With $n$ importable goods subject to different levels of distortions, the aggregate reduction in imports, in the absence of cross-price effects in all markets, is given by:

$$
\Delta M=\sum_{i=1}^{n} p_{i}^{* 2} d x_{i} / d p_{i}^{C} r_{i}-\sum_{i=1}^{n} p_{i}^{* 2} d y_{i} / d p_{i}^{P} s_{i}
$$

Setting the result equal to the reduction in imports from a uniform tariff, T, gives:

$$
\sum_{i=1}^{n} p_{i}^{* 2} d x_{i} / d p_{i}^{C} r_{i}-\sum_{i=1}^{n} p_{i}^{* 2} d y_{i} / d p_{i}^{P} s_{i}=\sum_{i=1}^{n} p_{i}^{* 2} d m_{i} / d p_{i} T
$$

Solving for $\mathrm{T}$, gives

$$
\begin{gathered}
\text { where } R=\left[\sum_{i=1}^{n} r_{i} u_{i}\right] \text { with } u_{i}=p_{i}^{* 2} \mathrm{dx}_{i} / \mathrm{d} p_{i}^{C} / \sum_{i} p_{i}^{* 2} \mathrm{dx}_{i} / \mathrm{d} p_{i}^{C}, \\
S=\left[\sum_{i=1}^{n} s_{i} v_{i}\right] \text { with } v_{i}=p_{i}^{* 2} \mathrm{dy}_{i} / \mathrm{d} p_{i}^{P} / \sum_{i} p_{i}^{* 2} \mathrm{dy}_{i} / \mathrm{d} p_{i}^{P} \text {, and }
\end{gathered}
$$




$$
\begin{gathered}
a=\sum_{i} p_{i}^{* 2} \mathrm{dx}_{i} / \mathrm{d} p_{i}^{C} / \sum_{i} p_{i}^{* 2} \mathrm{~d} m_{i} / \mathrm{d} p_{i}, \text { and } \\
b=-\sum_{i} p_{i}^{* 2} \mathrm{dy}_{i} / \mathrm{d} p_{i}^{P} / \sum_{i} p_{i}^{* 2} \mathrm{~d} m_{i} / \mathrm{d} p_{i}
\end{gathered}
$$

Evidently, the uniform tariff $\mathrm{T}$ can be written as a weighted average of the level of distortions of consumer and producer prices, $R$ and $S$ (the Consumer and Producer Assistance Indexes, respectively). An important advantage of using this decomposition of the index into producer and consumer effects is that it treats correctly the effects of non-tariff measures and domestic distortions that affect the two sides of the market differently.

In equation $3 c$ (equation $3 b$ ), the weights for each commodity are proportional to the marginal response of domestic production (consumption) to changes in international free-trade prices. These weights can be written as, among other things, functions of the domestic price elasticities (at the protected trade situation) of supply and demand $\left(\sigma_{i}\right.$ and $\rho_{i}$, respectively): ${ }^{7}$

$$
u_{i}=\rho_{i}\left(p_{i}^{*} x_{i}\right) / \sum_{i}^{n} \rho_{i}\left(p_{i}^{*} x_{i}\right) \text { and } v_{i}=\sigma_{i}\left(p_{i}^{*} y_{i}\right) / \sum_{i}^{n} \sigma_{i}\left(p_{i}^{*} y_{i}\right)
$$

The other index defined in Lloyd, Croser and Anderson (2010), the Welfare Reduction Index (WRI), measures the effect of a country's distortions on its economic welfare. The derivation follows the same steps as in the derivation of the TRI except that instead of starting from the loss in trade volume from a policy, one starts from a loss of consumer and producer surplus (a welfare loss, $\left.L_{i}\right)$. With $n$ importable goods subject to different levels of distortions, the aggregate welfare loss, in the absence of cross-price effects in all markets, is given by:

$$
L=\frac{1}{2}\left\{\sum_{i=1}^{n}\left(p_{i}^{*} s_{i}\right)^{2} \mathrm{dy}_{i} / \mathrm{d} p_{\mathrm{i}}^{\mathrm{P}}-\sum_{i=1}^{n}\left(p_{i}^{*} r_{i}\right)^{2} \mathrm{dx} \mathrm{x}_{i} / \mathrm{d} p_{\mathrm{i}}^{\mathrm{C}}\right\}
$$

The uniform tariff rate, $\mathrm{W}$, that generates an aggregate deadweight loss identical with that of the differentiated set of tariffs is determined by the following equation:

$$
\sum_{i=1}^{n}\left(p_{i}^{*} s_{i}\right)^{2} \mathrm{dy}_{i} / \mathrm{d} p_{i}^{P}-\sum_{i=1}^{n}\left(p_{i}^{*} r_{i}\right)^{2} \mathrm{~d} x_{i} / \mathrm{d} p_{i}^{C}=-\sum_{i=1}^{n}\left(p_{i}^{*} W\right)^{2} \mathrm{~d} m_{i} / \mathrm{d} p_{i}
$$

W is thus the uniform tariff which, if applied to all goods in the place of all actual tariffs and NTMs and other distortions, would result in the same

7. These expressions can also be written as functions of, among other things, the domestic price elasticities at the free trade points. 
aggregate loss of welfare as the actual distortions. Solving for W, we have:

$$
\begin{gathered}
W=\left\{R^{\prime 2} a+S^{\prime 2} b\right\}^{1 / 2} \\
\text { where } R^{\prime}=\left[\sum_{i=1}^{n} r_{i}^{2} u_{i}\right]^{\frac{1}{2}} \\
S^{\prime}=\left[\sum_{i=1}^{n} s_{i}^{2} v_{i}\right]^{\frac{1}{2}}
\end{gathered}
$$

with $u_{i}, v_{i}, a$ and $b$ as defined for equation 3 above. $\mathrm{W}$ is the desired Welfare Reduction Index, while $R^{\prime}$ and $S^{\prime}$ are the contributions to W from consumer and producer price distortions, respectively. They, like their appropriately weighted average $\mathrm{W}$, are means of order two. As with the index T, we can deal with, and analyse, the production and consumption sides of the sector separately.

\section{Extension to exportable sectors}

Lloyd, Croser and Anderson (2010) show how the indexes can each be extended to include the exportables sub-sector. This is facilitated by way of aggregating the import-competing and exportables sub-indexes where the weights for each sub-sector are the share of the sub-sectors' value of production (consumption) in the total value of production (consumption). The resulting measure is the import tax/export subsidy which, if applied uniformly to all products in the sector, would give the same loss of welfare as the combination of measures distorting consumer and producer prices in the import-competing and exportable sub-sectors.

In the case of the TRI it is important to keep separate track of the subsets of import-competing and exportable goods because the sign of an NRA in the exportable sub-sector (positive or negative) has the opposite effect on the TRI. That is, while an export subsidy in the exportable sub-sector reduces welfare in the same way as an import tax in the import-competing sub-sector, the export subsidy will increase trade and the import tariff reduces trade.

\section{Extension to nontradables sectors}

In this paper we extend indexes to include nontradable sectors. Because nontradables generally have low or zero distortions, an index that does not take into account these sectors will tend to overstate the trade- and welfare-reducing effect of overall agricultural policy.

To include nontradables, we keep separate track of three sub-sectors of the economy: import-competing, exportable and nontradable sub-sectors. We generate sub-sector-specific TRI and WRI indexes (as we previously did for each of the import-competing and exportable sub-sectors). The three sub-sector 
indexes are then aggregated using as weights each sub-sectors' share of value of production (consumption) in the total value of production (consumption).

For the WRI, because distortions in the nontradable sub-sector can cause welfare distortions, we proceed as expected and $s_{i}$ and $r_{i}$ values in equations $7 \mathrm{~b}$ and $7 \mathrm{c}$ are the actual level of distortion in the nontradable sub-sector.

For the TRI, however, we make an assumption that $s_{i}$ and $r_{i}$ values in equations $3 \mathrm{~b}$ and $3 \mathrm{~b}$ are zero. This assumption means distortions to nontradable products do not alter the sector's trade volume, and that the contribution of nontradables to the TRI is only through their share in the sector's total value of production (consumption).

\section{Why elasticities are of minor importance}

To assess how important is the simplifying assumption in this paper that the domestic price elasticities of supply are equal across commodities within a country, and likewise for elasticities of demand, consider the standard form of the Producer Assistance Index (PAI) from equation (7c):

$$
S^{\prime}=\left[\sum_{i=1}^{n} s_{i}^{2} v_{i}\right]^{\frac{1}{2}} \quad \text { with } v_{i}=p_{i}^{* 2} \mathrm{dy}_{i} / \mathrm{d} p_{i}^{P} / \sum_{i} p_{i}^{* 2} \mathrm{dy}_{i} / \mathrm{d} p_{i}^{P}
$$

This partial equilibrium measure can be broken down into three parts: ${ }^{8}$

$$
S^{\prime}=\left[\bar{s}^{2}+\Omega_{s}^{2}+\rho_{s}\right]^{\frac{1}{2}}
$$

The three parts are: - production-weighted average producer distortions, $\bar{s}=\sum_{i} s_{i} h_{i}$, where $h_{i}$
is the production share of good $i$;

- production-weighted variance of producer distortions, $\Omega_{s}^{2}=\sum_{i}\left(s_{i}-\bar{s}\right)^{2} h_{i} ;$ and

- the covariance between each producer distortion and its elasticity of output supply scaled by the production weighted average output supply elasticity, $\rho_{s}=\operatorname{cov}\left(\sigma_{i} / \bar{\sigma}, s^{2}\right)$, where $\sigma_{i}$ is the elasticity of output supply and $\bar{\sigma}=\sum_{i} \sigma_{i} h_{i}$

The formula makes explicit that an increase in the dispersion of producer distortions increases the partial equilibrium index relative to productionweighted average producer distortion. In addition, the partial equilibrium distortion index will be larger than the production-weighted average producer distortion when the covariance between supply elasticities and producer distortion

8. Kee, Nicita and Olarreaga (2008, p. 677) show the decomposition for the usual Anderson and Neary index, which is based on import volumes, import demand elasticities and trade distortion measures. 
measures is positive. An analogous decomposition can be derived for the Consumer Assistance Index (CAI).

In the absence of elasticity data across time and countries, it is possible to estimate PAIs, CAIs, TRIs and WRIs with the simplifying assumption that domestic price elasticities of supply are equal across commodities within a country, and likewise for elasticities of demand. The simplifying assumption equates to a computation of the PAI in which the third component of the decomposition shown above is zero.

Anderson and Neary (2005, p. 293) observe that elasticities are 'not very influential' in affecting trade restrictiveness indices because elasticities appear in both the numerator and denominator of the indices. In the PAI expression in equation 7c, for example, elasticities appear in both the numerator and denominator of the $v_{i}$ expression. In the third term of the PAI decomposition above, the elasticity for good $i$ is scaled by the production weighted average elasticity for all goods.

In empirical work, Kee, Nicita and Olarreaga (2008) note that the contribution of the covariance term to their estimates trade restrictiveness indexes is very small in practice. Irwin (2010), in his historical study of US trade policy, similarly shows that empirically the covariance is a very small factor relative to the average tariff and variance of the tariff. His estimated indexes depend almost entirely on the mean and variance of tariff rates, which are independent of elasticities.

Thus both theory and recent empirical analyses suggest reasonable approximations of the PAI, CAI, TRI and WRI can be obtained even when elasticity estimates are unavailable.

\section{REFERENCES}

Anderson, J.E. (2009a), ‘Consistent Trade Policy Aggregation', International Economic Review 50(3): 903-27.

Anderson, J.E., and J.P. Neary (2005), Measuring the Restrictiveness of International Trade Policy, Cambridge MA: MIT Press.

Anderson, K. (2009b), 'Five Decades of Distortions to Agricultural Incentives', chapter 1 in $\mathrm{K}$. Anderson (ed.), Distortions to Agricultural Incentives: A Global Perspective, 1955-2007, London: Palgrave Macmillan and Washington DC: World Bank.

Anderson, K., and J.L. Croser (2009), National and Global Agricultural Trade and Welfare Reduction Indexes, 1955 to 2007, database available at www.worldbank.org/agdistortions

K. Anderson, and W. Masters (eds.) (2009), Distortions to Agricultural Incentives in Africa, Washington DC: World Bank.

Anderson, K., and E. Valenzuela (2008), Global Estimates of Distortions to Agricultural Incentives, 1955 to 2007, database available at www.worldbank.org/agdistortions

Bach, C., and W. Martin, (2001), 'Would the Right Tariff Aggregator for Policy Analysis Please Stand Up?' Journal of Policy Modeling 23: 621-35.

Chen, S, and M. Ravallion (2010), 'The Developing World is Poorer Than We Thought, But No Less Successful in the Fight Against Poverty', Quarterly Journal of Economics 125(4): 1577-1625, November. 
Croser, J., and K. Anderson (2011), 'Changing Contributions of Different Agricultural Policy Instruments to Global Reductions in Trade and Welfare', World Trade Review 10, 2011 (forthcoming).

Croser, J.L., P.J. Lloyd, and K. Anderson (2010), 'How do Agricultural Policy Restrictions to Global Trade and Welfare Differ Across Commodities?' American Journal of Agricultural Economics 92(3): 698-712, April.

Feenstra, R. (1995). 'Estimating the Effects of Trade Policy', in G. Grossman and K. Rogoff (eds.), Handbook of International Economics, Vol. 3, Amsterdam: Elsevier.

Irwin, D. (2010), 'Trade Restrictiveness and Deadweight Losses from U.S. Tariffs, 1859-1961', American Economic Journal: Economic Policy 2: 111-33, August.

Kee, H.L., A. Nicita, and M. Olerreaga (2008), 'Import Demand Elasticities and Trade Distortions', Review of Economics and Statistics 90(4): 666-82, November. January.

Lloyd, P.J. (1974), 'A More General Theory of Price Distortions in an Open Economy', Journal of International Economics 4(4): 365-86, November.

Lloyd, P.J., J.L. Croser, and K. Anderson (2010), 'Global Distortions to Agricultural Markets: New Indicators of Trade and Welfare Impacts, 1960 to 2007’, Review of Development Economics 14(2): 141-60, May.

OECD (2010), Agricultural Policies in OECD Countries: Monitoring and Evaluation 2010, Paris: Organization for Economic Cooperation and Development.

Tyers, R., and K. Anderson (1992), Disarray in World Food Markets: A Quantitative Assessment, Cambridge and New York: Cambridge University Press.

World Bank (2007), World Development Report 2008: Agriculture for Development, Washington DC: World Bank. 